\title{
HOW THE DES MOINES VALLEY RAILROAD CAME TO DES MOINES.
}

BY TACITUS HUSSEY.

There has ever been a strong bond of friendship between the early settlers of Des Moines and the city of Keokuk, Iowa. This friendship began when that city on the Mississippi was a young and bustling town and Fort Des Moines was a little, muddy, smoky hamlet at the "Raceoon Forks of the Des Moines river." Keokuk, in those days, was our Chicago; for there we used to get our supplies. There come up in our memory the capacious warehouses of Chittenden \& McGavic, Conable, Smyth \& Co., B. B. Hinman \& Co., Foote \& Co., J. B. Carson, Stafford \& McCune and others, perhaps, situated on or near the levee, where consignments of goods were stored intended for the interior of Iowa, waiting transportation by boat, during the boating season on the Des Moines river, or by wagon during the dry seasons over a wild prairie, in summer's heat, autumn's haze and through winter's snow-drifts.

Keokuk bears the name of the "Gate City." A very appropriate cognomen; for through this gate nearly all the shipments to Des Moines passed for consumption here and for distribution to the scattered villages and sparsely'settled country which surrounded them. There was another bond of friendship which united these two eities. In the beginning of the dark days of 1861, with tears and prayers, we followed some of our young men who had sprung to their country's call, to that eity, where they were uniformed, armed and drilled for the bloody work to which. they were called, and watched them as they were carried away by boat and rail to the front, amid tears, cheers and streaming banners.

It was there that Miss Allie Smith, a little Keokuk girl twelve years of age, with an upturned barrel for a platform sang war songs to the soldiers, cheering the homesick ones, causing the hearts of all to throb with renewed patriotic resolves. As Mrs. Allie Smith Cheek, of this city, her voice has 
lost none of its sweetness and flexibility, as every army post and camp-fire in Iowa will gladly testify.

There is another bond of friendship between these two cities which will never be forgotten by the pioneers of Des Moines. In January, 1857, the Constitutional Convention met in Iowa City and formulated a new constitution which was to be submitted to the voters of Iowa in August of that year. In order to make the location of the Capital at Des Moines doubly sure, the following clause was inserted at the instance of some of the prominent Des Moines citizens: "The seat of government is hereby permanently established as now fixed by law, at the city of Des Moines, in the county of Polk, and the State University at Iowa City, in the county of John. son." For jealousy, or some other reason, the various counties of the State opposed the adoption of this Constitution and voted against it vigorously. The people of Polk county being intensely interested, raised a subscription of $\$ 100,000$ to aid the Des Moines Valley Railroad, and gave a majority of 1,500 for the new Constitution. Lee county, in return for this very high compliment to its pet railroad line, gave an immense majority for the Constitution-and saved the day! But it was a tight squeeze; for the entire State majority was only about 1,600 .

On a high, rocky bluff, now overlooking the canal and the Mississippi river to the east, the writer stood alone one sunny afternoon in June, early in the fifties, and was so charmed with the beautiful prospect spread out before him that it has been retained in his memory ever since. He remembers say. ing to himself. "What a magnificent view! What a spot this would be for a mansion fronting the west, with a wide porch looking to the east. What a place for a man who has successfully fought the battle of life, gained a competency and upon whose shoulders life's cares rest lightly, to sit and dream away the remaining hours of life!' But my reminiscent pen has run away from the subject I set out to tell "How the Des Moines Valley Railroad came to Des Moines."

It took nearly twelve years to build this railroad from Keo. kuk to Des Moines. Four regular sessions of the Legislature had been held here, and another was almost due, when the 
first train came into the city. The project and the work of carrying it to a successful finish, was little short of heroic. Four years previous to the throwing of a single shovelful of dirt there had been an unprecedented flood which had swept the valley of the Des Moines clean of crops, stored and growing, live stock, fences. and in fact all floatable articles and filled the Mississippi with all sorts of floating debris. The farmers on the upland did not fare much better, as the continuous rains prevented planting and washed the ploughed fields into unsightly ditches. Iowa came as near to a crop failure and Des Moines to a food famine as ever before or since. It took three or four years to recuperate. Then there was financial difficulty. Gold and silver, what little there was, had gone into hiding. Currency was of the doubtful kind, being free bank money from Indiana, Illinois and Iowa "wild cat currency."

The officers of the road in 1855-56 were: President, H. T. Reid, afterwards a gallant soldier in the Civil War and an accurate historian; secretary, C. F. Conn; treasurer, W. C. Graham, and a board of directors. Grading began in 1855 when a contract was let to Bentonsport, a distance of forty miles. The rails for this distance were ordered by eastern capitalists, September, 1855, and were expected in 1856. Grading began again in March, 1856, although the frost was. not yet out of the ground. The contractors who were to fur. nish the ties were going on with their work. On June 17th, 1856 , the good news was received that 4,000 tons of the rails ordered, costing $\$ 64,000$, had arrived at New Orleans and were on their way up the river on seven steamboats. When the boats arrived track-laying began without ceremony and on the seventh day of October of that year, the first "Excursion train on the D. V. R. R" started from the depot ground"s in Keokuk for the first station, Buena Vista. The locomo. tive pulling this first train had been christened "Des Moines," as a compliment, no doubt, to the city in the dim distance at the terminus of the road. The passengers were: President Reid, Messrs. Eaton, Roberts, Leighton, Parsons and others of the directory board, together with a number of citizens unnamed, but who, no doubt, wished to go down in 
history as passengers on the first train out of Keokuk. Track was at this time being laid at the rate of half a mile $\varepsilon$ day, and it was estimated that by December first the road would stretch out twelve miles, ever pointing hopefully to its destination.

There began on the first day of December, 1856, an un. precedented snow-storm, lasting three days, followed by a blizzardly wind which heaped up the snow all over Iowa from one to ten feet deep, making the graded work look like an elongated grave of buried hopes. But under a somewhat belated spring sun the snow-drifts wept themselves away, and on June 10th, 1857, Farmington welcomed the "Iron Horse" with loud acclaim, fed and encouraged the officers of the road and the welcome visitors who accompanied them and with a Godspeed waved them on to their journey's end. Bonaparte was passed in due time, and in the spring of $1858^{\circ}$ the road had reached Bentonsport in time to carry to their homes some of the members of the first Legislature Des Moines ever had. Those members who could in any way reach home by boat, embarked on the steamer "Skipper," arriving safely at their destination and thence by railroad to their several homes. These members had been courted, had feasted and danced during the winter and left the new Capital in the best of spirits. The first Legislature, the first railroad and the first arrival of a steamboat in the spring were events which caused the heart of the average Des Moines citizen to swell with pride. The Republican State Convention met in Des Moines in 1859, and the entire delegation from Dubuque, one member of which was Frank W. Palmer, came up as far as Agency City, the then terminus, by rail, and thence by boat to Des Moines. All the delegates who could, came in the same way and were loud in their praises of the quickness of the trip and the courteous treatment accorded them.

In the spring of 1862, all the members of the Legislature on adjournment, who could reach, home by river, embarked on the "Des Moines City" to Ottumwa, and were carried. to their homes by the Dès Moines Valley Railroad Company. Then by slow and easy stages the road crept up to Eddyvil!e, where it found a tarrying place during a portion of the years 
when the war was going on, and where it was met by the "Des Moines Steamboat Line" as it advertised itself. This line was used to transport the outgoing troops and return the sick, wounded and furloughed soldiers who had been to the front, smelled powder to their cost, and returned home to be nursed back into health and strength by tender hands and loving hearts. But little by little the railroad crept up the river and on July 10th the readers of the Daily Register smiled over one of J. M. Dixon's characteristic couplets:

\section{Sammum Hillum! Something's broke!}

The ears have got inside of Polk'!

The news had been brought in by a farmer, who, with beaming face, gave the pleasing information that track-laying and a construction train had penetrated Polk county nearly half a mile! Then we began to hear of it at "Woodville," only a few miles away; for stages met the passengers there for a while and the hearts of the Des Moines people began to beat high with hope, especially after being in the presence of and talking with the men and women who were congratulat: ing themselves on coming to Des Moines with so little staging. On the 22d of August our citizens were regaled by the following :

\section{PROCLAMATION.}

Hear, oh, ye heavens and give ear, oh, ye earth! Let the glad news sweep over the prairies and around the universe, that the first train on the Valley Road will come into Des Moines on the afternoon of the 29th of Angust, 1866! Colonel Leighton says it, and his word stands fast! In view of this circumstance, preliminary arrangements should be made to meet the Iron Horse and give him a grand reception! Let the mayor and city council lead off in this matter. About forty persons from Keokuk will come up on the train as railroad delegates to Des Noines, and there should be marching, bonfires, music, hurrahing, whistling, yellings, and circumscribed and uncircumscribed rippings and tearings through all this Land of Promise! Let us have a perfect roar and rush and thunders of enthusiasm!

Accordingly a public meeting was held at the city coun. cil room to make arrangements for the coming event. Mayor Geo. W. Cleveland was called to the chair and Seward Smith appointed secretary. John Morris moved that a committee of seven, of which the mayor should be chairman, should be selected to take the matter in charge. The committee chosen 
was as follows: P. M. Casady, J. M. Moody, John Morris, B. F. Allen, S. F. Spofford, and George W. Jones. They were given full power to complete the arrangements. On motion of Judge Casady, Mayor Cleveland was authorized to invite the mayor and city council of Keokuk to visit Des Moines on the first train. The meeting then adjourned to meet on the following Saturday, at which time the city council would be asked to make such appropriation as would meet the bills of the committee of arrangements. At the meeting thus appointed Col. E. F. Hooker was elected marshal of the day, Col. E. S. Spofford was appointed committee on transportation of visitors, and John Morris on music, artillery and ringing of the bells of the city.

A supper and dance was appointed at the Savery House (now Kirkwood) and given into the hands of Geo. A. Drake, Ten Eyck Beekman and Major Joseph Lyman, with such sub-committees as might be required.

Honorable Geo. W. Jones, Col: E. F. Hooker, and Ccl. Stewart were appointed a committee on program and they at once selected Hon. John A. Kasson to make the speech of welcome. Other speakers to be called out by the chairman: if desired. The arrangements were as follows:

ORDER OF EXERCISES AND PROCESSION.

1. Collard's Brass Band,

2. Mayor and City Council,

3. Invited Guests,

4. Masonic Order,

5. Odd Fellows,

6. Good Templars,

7. Citizens on Foot,

8. Carriages and Equestrians.

MARSHALS:

Col. E. F. Hooker, Chief Marshal,

Col. S. F. Spofford, 1st Assistant,

Joseph C. Warner, 2d Assistant,

Harry Stephenson, 3d Assistant,

Augustus Newton, 4th Assistant,

John Bacon, 5th Assistant.

Returning, procession will form in the same order from depot on Market street, thence from Market to Fourth, from Fourth to Court Avenue, from Court Avenue to Third street, up 'Third to Walnut, up Walnut to Savery House, where the procession will be dismissed by Hon. George G. Wright.

When the whistle sounded somewhere near the Brooks 
farm on the afternoon of August 29, 1866, the crowd with one accord shouted: "She's a coming!" When the train came in sight, as far down the track as could be seen, there was a wilderness of handkerchiefs, hats and hands waving from the windows of the cars, while on the crowded platforms could be seen men waving their hats and shouting their grectings to the assembled crowds on both sides of the track. When the stop was finally made there were speeches, but not a third of the crowd heard them. They were too happy to listen. A majority preferred to inspect the cars and shake hands with the engine, so to speak. Many of the assembly had never seen a train of cars, especially the younger portion of the generation. Some of the older ones had not seen a train since they bid adieu to the railroad on the east bank of the Mississippi years ago, as they journeyed into Iowa with eyes fixed on "Fort Des Moines," the prospective Capital of the State.

John A. Kasson was at his best that day, as was also Judge Wright, who had been "waiting for the wagon" for the last twenty-five years. His face beamed with the satisfaction he felt, and he convulsed the listeners with some of his oldtime stories of early transportation, by ox team, stage and steamboat. The visitors responded in their happiest vein and the crowd was the jolliest ever seen and heard in Des Moines. And the women! They were there in great numbers; for where the men are, there will the women be also.

Then the procession was formed and the march to the Savery House, Fourth and Walnut, was made in the same order as the previous procession, yet with much more enthusiasm and noise. All were so happy that they had to give vent to their enthusiasm in some way and it generally took the form of shouting and singing. When the destination was reached the procession was dismissed by Judge Wright in a few well-chosen words and the procession melted away. The visitors were assigned to the Savery, the De Moine House and other hotels, while not a few were taken care of by friends and acquaintances at their private residences. The people of Des Moines seemed to be fully in accord with one of the voices of the day, which said: 
They waited for its coming! They prayed for its coming! They talked of its coming until their tongues grew eloquent with the themel But they died and were in their graves before their eyes saw the glories of this latter age! Through the films of death they struggled to see the glory; but a cloud from the Shadowy Land, freighted with the chills of the grave intercepted all vision and encompassed the dying with universal darkness! It is here! All doubts have fled! The great triumph has been achieved! The promised train is here today! The sun shines in a clear firmament! The day, yea, the hour of final victory has come!

The supper and dance at the Savery House was all that could be wished and was enjoyed until a late hour of the morning. Some of our staid citizens did not go to bed at all, but "made a night of it!" Des Moines never saw a happier throng of eitizens, and none was more happy than Judge Wright, Juidge Casady, B. F. Allen, Col. Spofford, Col. Hooker, J. B. Stewart, Thomas Hatton, Ed. R. Clapp, Geo. W. Jones, Col. Stewart and hundreds of others who had waited for years for the coming train which was to bind Des Moines in bands of iron to the outside world, and cause her to stretch her limbs in the great race of preferment.

Nearly forty-one years ago! What changes have come to the then village just waking to a sense of her importance! How many of the active participators in this city are alive? How many of the honored guests remain in the flesh to look back upon this most important step in the progress of Central and Western Iowa?. For the benefit of the younger generation, a list of the guests are given that they may go down into history as participants in the first railroad excursion to the Capital of the greatest State in the Union:

From Keokuk-J. M. Billings, S. C. Carter, D. Payne, J. Jewell, R. Patch; E. Griswold, Judge S. F. Miller, B. S. Meriam, E. H. Wickersheim, E. J. Leech, J. W. Delaplain, Wm. Patterson, mayor of Keokuk; James Coy, William Thompson, J. C. Patterson, S. P. Patterson, Harry Fulton, W. Wilson, John P. Wise, Geo. E. Kilburne, Captain Ball, Major Lowe, J. L. Rice, C. Bailey, Col. J. A. Viall, D. Urinick, J. K. Cochran, D. B. Drummond, C. Gaber, C. Thompson, H. Kerr, W. Sample, Capt. Add Hine and son, Gen. H. T. Reid and son, Howard Tucker, Wm. Brownell and son, H. J. Miller, Jas. H. Wilson, Joseph L. Herr, Captain Pearmain, General MeKenney, Geo. J. H. Wilson, U. S. A.; Col:- C. P. 
Haines, H. A. Whitney, Isaac Anderson, S. M. Anker, W. N. Stannus, H. Robertson, S. Pollock, W. S. Roche, B. Williams, Michael Gregg, James Mayer, G. W. Kerr, Col. A. W.' Sheldon, E. H. Jones, W. C. J. Vines, G. W. Pittman, Rev. Mr. Hassall, H. S. Farrer, Sam M. Rankin, D. Mooar, M. K. Taylor, C. P. Birge, James C. Bruce, E. Sellers, J. W. Rankin, Col.!D. B. Hillis, J. R. Copelin, H. B. Ten Eyck, Col. J. C. Parrott, R. H. Wyman, A. C. MeQueen, Hon. J. W. McCreary, H. T. Cleaver, I. N. Sterne, Gen. W. W. Belknap, Doc Lowe, D. W. Blackburn, A. J. Wilkinson, George E. Yarman, S. Cary, S. Younker, George Cabus, P. D. Foster, H. W. Bobsnik, J. M. Hiatt, Rev. John Burgess, D. W. Tucker, C. E. Snow, John W. Bowers, J. W. Pearmain, J. Gush, E. M. Buell, Geo. L. Coleman, P. Gibbins, Geo. B. Smith, A. Bridgeman, O. C. Hale, Thomas Clyde, Thomas J. Tucker, J. J. Goodwin, George R. Stafford, J. P. Carl, J. Tibbetts and Alex Barclay.

From Oskaloosa-W. H. Seevers, J. R. Needham, M. T Williams, Geo. J. Bennett, W. H. Needham, E. Moore, D. W. Loring, and C. G. Moss.

From Burlington-A. D. Wentz, L. Carper, E. Chamberlạin, Mark S. Foote, C. P. Squires, James Morton, A. G Adams, Dr. Beardsley, James Pittman; H. E. Hunt and T. W. Barhydt.

From Ottumwa-Gen. J. M. Hedrick, J. Howley, Jr., Hon. E. H. Stiles, Gen. E. Gillespie, E. M. Gibbs, J. J. Robison, and W. H. Caldwell.

The same train took the excursionists back the next day and bore on one side of the engine a banner reading: "Keo-. kuk-Des. Moines-the gate open to the Capital." On the other side of the engine a banner. read: "D. V. R. R.-The link which unites us."

And the train moved out across the wide stretch of prairie amid the good-byes and cheers of the happiest people in Iowa. And thus Des Moines shook hands with the outer world by rail.

The first locomotive entering Des Moines was the "Marion," on the 28th day of August, with rails to finish laying the track, James Carl, engineer. The engine bringing 
in the "excursion train" on August 29, 1866, was the "Keokuk, No. 1," James Tibbetts, engineer, and R. Patch, conductor. .

Robert Given, now of Dallas, Texas, was conductor of the first freight train entering Des Moines, August 30th, 1866, drawn by the "Leighton," Jack McKeachie, engineer. This train brought up a big consignment of lumber for $\mathrm{H}$. F. Getchell \& Co.

Some years after this, a "chesty." individual; wishing to say something smart, in speaking of the "Gate City;" remarked that the "Gate" had been left open and business had sauntered out never to return! Well, never mind. When the Mississippi river is improved with a six-foot channel from St. Anthony's Falls to the mouth of the Missouri, and thence with a fifteen-foot channel to the sea, and the Des Moines river, by canalization, becomes an arm of the great waterway system which is to be, our old sweetheart will come to her own again!

Des Moines, Iowa.

The WESTERN PLAINS are literally covered with buffalo. The number each year seems to increase rather than diminish. They go in immense droves and at times seem to cast a dark shadow over the valley.-St. Charles City Intelligencer, September $25,1859$.

NoTice is given that the Synod of Iowa will meet in the First Presbyterian Church, at Vinton, on the fourth Thursday (22d) of September, at half past seven o'clock. p. m. Arrangements have been made with the Western Stage Company, the Railroad and Steamboat Companies, to return persons in attendance on the Synod free, who have paid fuil fare one way.-St. Charles City Intelligencer, September 8, 1859. 
Copyright of Annals of Iowa is the property of State of Iowa, by \& through the State Historical Society of Iowa and its content may not be copied or emailed to multiple sites or posted to a listserv without the copyright holder's express written permission. However, users may print, download, or email articles for individual use. 